Neurologia medico-chirurgica, $13: 46 \sim 58,1973$

\title{
The Role of Cyclic 3', 5'-AMP on Trauma-Induced Alteration of Energy Metabolism in Cerebral Cortex
}

\author{
in vivo
}

\author{
Hiroshi WatANABE and Shozo IsHII*
}

Introduction

Cyclic AMP has becn proposed as the mediator of the catcholaminc-induced activation of phosphorylase and glycogenolysis 1), and the concentration of cyclic AMP, together with enzymes for its synthesis and degradation, is particularly high in the central nervous system ${ }^{2), 3), 4), 5), 6) . ~ K a k i u c h i ~ a n d ~ R a l l ~}{ }^{4}$ have shown that norepinephrinc as well as histamine elevates levels of cyclic AMP in slices of cerebral cortex. Electrical stimulation to brain slices? or to the brain of intact animals has caused several-fold increase in cyclic $\mathrm{AMP}^{8 \mathrm{8}}$. In a preliminary study, Watanabe and Passonneau ${ }^{9)}$ observed a 6- to 7-fold increase in brain cyclic AMP following stab wound injury, however, no definite role of this substance has been determined yet in brain.

Enzymatically catalyzed formation of cyclic AMP from ATP10),11) and the affection of clycic AMP to glycogen metabolism through the interconversions of glycogen synthetase and glycogen phosphorylase imply the possible biochemical role of cyclic AMP in the cnergy metabolism in injured brain.

In the present investigation, the alterations in glycogen and related energy metabolism in relation to the increased cyclic $\Lambda \mathrm{MP}$ induced by experimental brain injury were studied to elucidate possible biochemical lesions. The concentrations of glycogen and the metabolites associated with glycogenesis and glycogenolysis have been determined. The effect of injury on glycogen turnover has been assessed from the rate of incorporation of ${ }^{14} \mathrm{C}$ from glucose into glycogen and the subsequent rate of loss. The activitics and forms of glycogen synthetase (EC 2. 4.1.11) and glycogen phosphorylase (EC 2.4.1.1.) have been measured in injured and sham-opcrated animals. The metabolic rate of the injured brain has been compared with that of control animals at various times after injury by the measurement of the rate of utilization of P-creatine, ATP and glucose and the rate of formation of lactate in isolated brain samples. The alteration in the levels of cyclic AMP due to injury was measured under drugs known to affect cyclic AMP metabolism.

\section{Materials and Methods}

\section{Animals}

Male mice of NIH strain weighing 20-25 g were starved for $10 \mathrm{~h}$ beforc use. A midline skin incision was made in the scalp and a 27 -gauge hypodermic ncedle in-

* Correspondent: Hiroshi Watanabe, M.D. Dept. of Neurosurgery, Juntendo University School of Medicine, Hongo, Tokyo, Japan 
serted vertically through the skull into the cerebral hemisphere $5 \mathrm{~mm}$ in depth at a point $2 \mathrm{~mm}$ posterior to the coronal suture and $3 \mathrm{~mm}$ lateral to the sagital suture. Because the animals werc not ancsthetized and stress may be a factor, sham-operated animals were used as controls. The wound was closed with skin clips. When radioactive glucose was given, $15 \mu \mathrm{Ci}$ of ${ }^{14} \mathrm{C}$-glucose was injected via the tail vein in a volume of approximately $0.1 \mathrm{ml}$. The glucose $(180 \mathrm{mCi} / \mathrm{mmole})$ was obtained from International Chemical and Nuclear Corp., Irvine, Calif. When drugs were used the animals were given an intraperitoneal injection of $0.2 \mathrm{ml}$ at various intervals prior to injury, and frozen at 1 min after injury.

\section{Sample preparation}

Blood samples were taken from the retrobulbar plexus in heparinized capillary tubes and the plasma was immediately separated by centrifugation. Blood glucose was measured as described by Nelson et al. ${ }^{12}$ ). Whole mice were frozen with rapid stiring in liquid $\mathrm{N}_{2}$ and a $20 \mathrm{mg}$ portion of the frozen cerebral cortex from the vicinity of the lesion was dissected in a cryostat at $-20^{\circ} \mathrm{C}$. The samples were stored at $-50^{\circ} \mathrm{C}$ until the extracts were made, as described by Brunner et al. ${ }^{13)}$. For the measurement of glycogen synthetase and glycogen phosphorylase activity, a $20 \mathrm{mg}$ portion was prepared according to Passonneau and Rottenberg ${ }^{14)}$ and Breckenridge and Norman ${ }^{15)}$, respectively.

\section{Radioactivity measurement}

For radioactivity measurcments, glycogen was isolated from $40 \mathrm{mg}$ of brain by a modification of the method of Kerr. The radioactivity and the glycogen content of the isolated samples were determined according to Watanabe and Passonneau ${ }^{16)}$. To measure the radioactivity of blood glucose, $2 \mu \mathrm{l}$ of blood plasma were pipetted into a scintillation vial containing $10 \mathrm{ml}$ of Aquasol (New England Nuclear Corp., Boston, Mass.).

\section{Metabolite and enzyme analyses}

All enzymes were obtained from Bochringer Mannheim Corp., New York, N.Y., except glycogen phosphorylase which was purchased from Sigma Chemical Co., St. Louis, Mo. Fluorometric analyses of metabolites and enzyme activities were made according to the following procedures: glycogen (Passonneu et al. ${ }^{17}$ )); glucose and glucose-6-P (Lowry et al. ${ }^{18)}$ ); UDP-glucose and plasma glucose (Nclson et al. ${ }^{12}$ ); glycogen phosphorylase (Lowry et al. ${ }^{19}$ )); glycogen synthetase (Passonncau and Rottenberg ${ }^{1: 4)}$ ); cyclic AMP (Gilman ${ }^{20)}$ ).

\section{Results}

\section{Effect of brain injury on the levels of brain glycogen}

The changes in brain glycogen as a fuction of time after brain injury are shown in Table 1 . The glycogen levels were dramatically reduced $10 \mathrm{~min}$ after the stab wound (57\% of controls, $\mathrm{P}<0.005)$. At $30 \mathrm{~min}$, glycogen levels in the injured brains were slightly higher than at $10 \mathrm{~min}$, and at $1 \mathrm{~h}$ were not different from control values. Subsequently, glycogen was accumulated in the injured cerebral cortex, reaching a maximum concentration at $2.5 \mathrm{~h}$ after injury. The levels of glycogen in injured animals remained relatively constant for $24 \mathrm{~h}$. 


\section{Changes in levels of metabolites related to glycogen}

The effect of brain injury on the levels of metabolites related to glycogen and on blood glucose was examined. Concentrations of glucose, glucose-6-P, UDP-glucose, and plasma glucose at various times following injury are shown in Table 2. The brain glucose in the injured cortex was less than half that of control animals $1 \mathrm{~min}$ after injury $(\mathrm{P}<0.005)$, while $10 \mathrm{~min}$ after injury brain glucose was significantly increased $(\mathrm{P}<0.001)$. The concentration of plasma glucose did not change: consequently, the ratio of brain to plasma glucose decreased at $1 \mathrm{~min}$ after injury and increased after $10 \mathrm{~min}$. The glucose content of the injured brain remained significantly higher than controls $60 \mathrm{~min}$ and $24 \mathrm{~h}$ after injury, and the ratio of brain to blood glucose also remained elevated.

The changes in glucose- $6-\mathrm{P}$ concentration in the cortex resembled those of glucose. The glucose-6-P levels were decreased at 1 min, and increased 10 min after injury (Table 2). The concentration of UDP-glucose was unaffected by injury.

Metabolic rate during brain injury

The pattern of changes in P-creatine, ATP and glucose measured at intervals after injury was quite similar (Iable 3). There was an initial drop in the concentrations of these substances, the lowest levels being observed at $1 \mathrm{~min}$ after injury. Although glucose was not measured in all cases, the low levels of glucose at 10 and 30

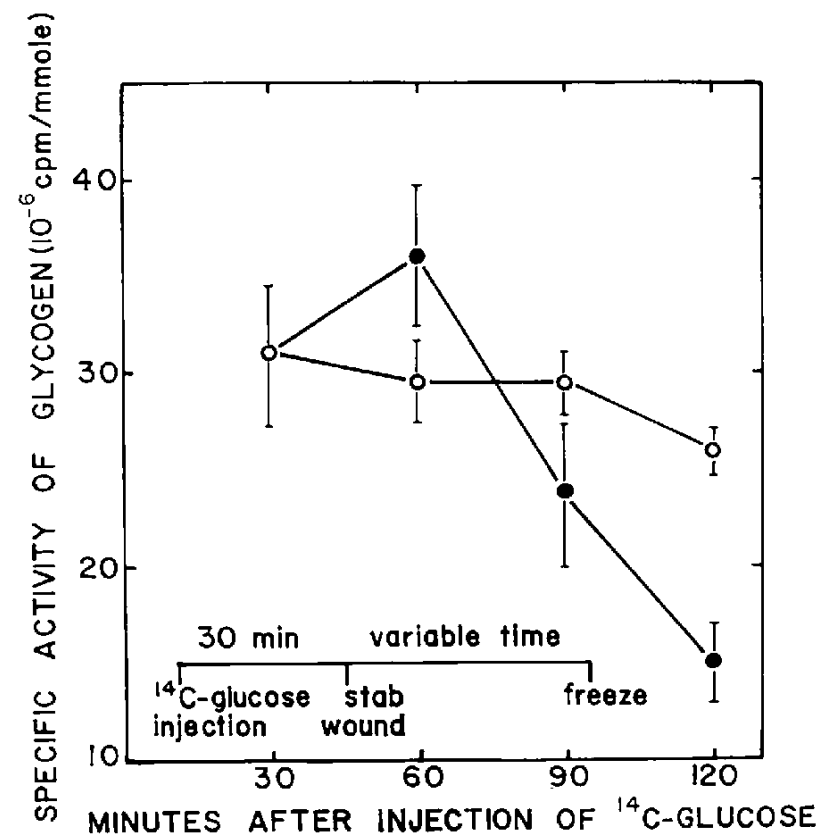

Fig. 1 Effect of brain injury on the turnover of cerebral glycogen. Mice were injected intravenously with $\left[\mathrm{U}-{ }^{14} \mathrm{C}\right]$ glucose $(15 \mu \mathrm{Ci} / 20 \mathrm{~g})$, the brain injured $30 \mathrm{~min}$ later, and the mice killcd by rapid-freezing at various times after injury. Glycogen was isolated from the injured cortex and the amount of glycogen and the radioactivity measured as described in the text. Mean values \pm S.E.M. are given for 4 animals at each time interval. 0 , control; -, injured. 
sec and $1 \mathrm{~min}$ after injury agree with the observation (Table 2) that there was an initial fall in glucose in injured cortex. Lactate concentrations were increased, presumably due to ischemia and consequent anoxia with resulting anaerobic glycolysis. The highest level of lactate was observed at 1 min after injury, after which lactate decreased, reaching normal values $24 \mathrm{~h}$ later.

In order to assess metabolic rate at these times, a second group of animals was decapitated and frozen $10 \mathrm{sec}$ later (Table 3). The sum of the changes in P-creatine, ATP and glucose or lactate was used to calculate the metabolic rate ${ }^{18)}$. The metabolic rate in control mice agrees with values reported in the literature ${ }^{13)}$, 18). Ten seconds after injury, the metabolic rate is near normal, but at $30 \mathrm{sec}$ and $1 \mathrm{~min}$ after injury the metabolic rate is depressed to almost $50 \%$ of that of control animals. Subsequently the matabolic rate increased to $150 \%$ of control rates at 10 and $60 \mathrm{~min}$ after injury. After $24 \mathrm{~h}$ the metabolic rate of injurcd brain had returned to normal.

\section{Effect of brain injury on the turnover of brain glycogen}

The effect of brain injury on the turnover of cerebral glycogen was examined. Mice were injected intravenously with ${ }^{14} \mathrm{C}$-glucose, the brain was injured $30 \mathrm{~min}$ later, and the animals killed at various times after injury (Fig. 1). Maximum labeling was found $30 \mathrm{~min}$ after injection of ${ }^{14} \mathrm{C}$-glucose in the control animals and decreased slowly thereafter. The specific activity of the cerebral glycogen in the injured mice increased to a maximum at $1 \mathrm{~h}$ and subsequently decreased rapidly.

The specific activity at $120 \mathrm{~min}$ (90 min after injury) was $50 \%$ of control values.

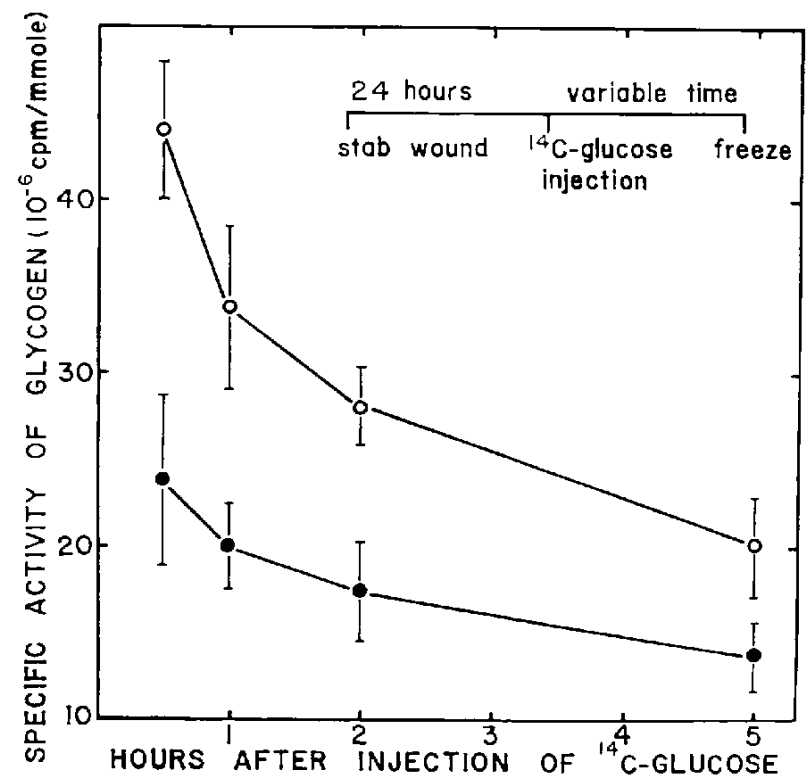

Fig. 2 The turnover of brain glycogen in control and injured mice. Mice were injected intravenously with $\left[\mathrm{U}_{-}{ }^{14} \mathrm{C}\right]$ glucose $24 \mathrm{~h}$ after brain injury. The glycogen was extracted, analyzed and the radioactivity measured as described in the text. Mcans \pm S.E.M. are given for 4 animals at each point. $O$, control; $\bullet$, injured. 
The increased rate of incorporation of ${ }^{14} \mathrm{C}$-glucose into glycogen together with the accelerated rate of loss radioactivity (Fig. 1) suggest that both synthesis and degradation of glycogen are increased in the early stages following brain injury.

The turnover of brain glycogen in control and injured mice $24 \mathrm{~h}$ after injury is shown in Fig. 2. The specific activity of the glycogen at this time in the injured animals was $23.8 \times 10^{6} \mathrm{counts} / \mathrm{min} / \mathrm{mmole}$ compared to $44.4 \times 10^{6} \mathrm{counts} / \mathrm{min} / \mathrm{mmole}$ in the control animals. The peak of the specific activity of glycogen occurred at $30 \mathrm{~min}$ in both control and injured animals. 'The ratio of specific activity of the glycogen from control and injured animals parallels closely the ratio of the cerebral glycogen content at $24 \mathrm{~h}$ after injury (Table 1). Unlike the carlier stages of injury (Fig. 1) the turnover of glycogen was decreased in injured animals. The half-times for loss of radioactivity from glycogen in control and injured animals were 2.5 and $3.5 \mathrm{~h}$, respectively.

Glycogen synlhetase and phosphorylase in injured brain

Because of the striking changes observed in brain glycogen following injury the activities of the enzymes involved in glycogen synthesis and breakdown were measured. The percentage of glycogen synthetase I (independent of glucose-6-P) to total activity at different times following brain injury is shown in Table 4.

At 1 min after injury there was no significant difference in the per cent of glycogen synthetase activity in the 1 form belwecn injured and control brains. However, the per cent of synthetase in the I form was greater in both cases than in non-operated animals $(26.8+1.0)$. The per cent of synthetase activity in the I form was significantly elevated over the corresponding control value $10 \mathrm{~min}$ following injury. Surprisingly, this increase in I activity, which is the active form of synthetase, was concomitant with the greatest decrease in the level of glycogen (Table 1). Twenty-four hours after injury the per cent synthetase I activity was less than that of the control, despite the observation that brain glycogen was significantly increased. No changes in total synthetase activity were found in any group $(14.7-3 \mathrm{mmole} / \mathrm{kg} / \mathrm{h})$.

Glycogen phosphorylase in brain has been shown to exist predominantly as phosphorylase $b$ in quick-frozen brain and is rapidly converted to phosphorylase $a$ following ischemia ${ }^{15)}$. The percentage of glycogen phosphorylase a compared to total activity (as measured by velocity in the absence and presence of $\Lambda \mathrm{MP}$ ) is shown in Table 4. Phosphorylase activity almost doubled 1 min after brainin jury $(P<0.005)$ and remained elevated after 10 and $60 \mathrm{~min}$. This observation agrees well with the decreased glycogen at $10 \mathrm{~min}$ ('lable 1 ) and increased glycogen turnover $1 \mathrm{~h}$ after a stab wound (Fig. 1). The per cent phosphorylase a returned to control values after $24 \mathrm{~h}$, when glycogen breakdown was decreased (Fig. 2). As with the synthetase there were no significant changes in the activitics of total phosphorylase in any group (12l-1 $6 \mathrm{mmole} / \mathrm{kg} / \mathrm{h}$ ).

Changes in levels of cyclic AMP following brain injury

The time course of the changes in cyclic AMP concentration in cerebral cortex following brain injury is shown in Fig. 3. Cyclic AMP in injurcd cortex increased rapidly to maximum value at 1 min after injury $(73.1 \%$ of controls, $P<0.001)$. Thereafter it progressively decreased but was still significantly higher than controls $10 \mathrm{~min}$ after injury. The values at 30 and $60 \mathrm{~min}$ after injury were not significantly different from control. 

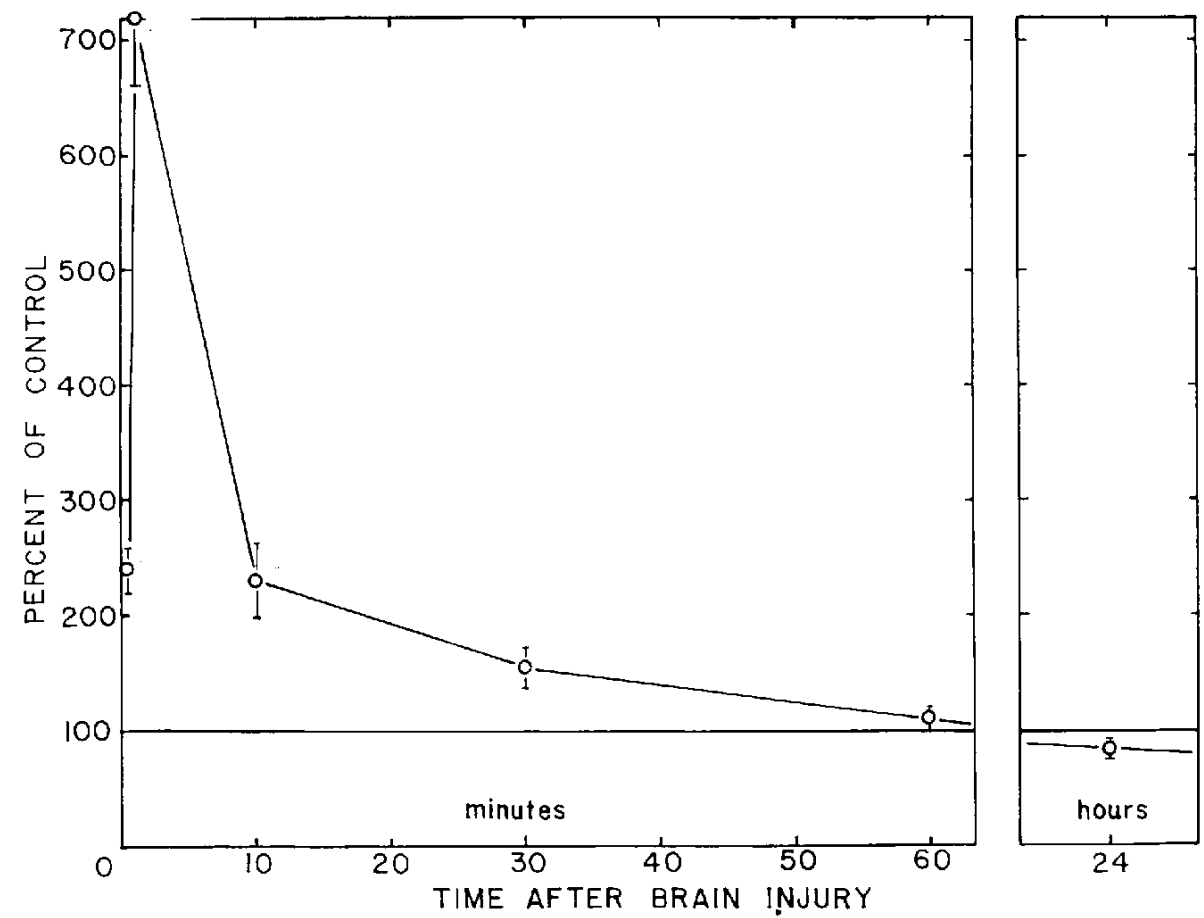

Fig. 3 Effect of brain injury on the levels of cyclic AMP in cerebral cortex. Mice were quickfrozen at various times after stab wound injury. Cyclic AMP' was measured as described in the text. Each point represents the mean of values obtained for 4 animals.

Effect of centrally acting drugs on the cyclic AMP accumulation due to injury

It has been shown that the formation of cyclic AMP is increased by catecholamines and/or histamine in slices from brain31,4),21). Burkard22) showed that several catecholamines injected into the cerebral ventricles of rats increased the brain cyclic AMP. Potential antagonists of norepinephrine and histamine were used to determine whether they would block the increases in cyclic AMP following injury. Neither dichloroisoproterenol (DCI) nor pronethalol had a consistently significant effect on the accumulation of cyclic AMP, although the cyclic AMP was considerably lower after injury if $10 \mathrm{mg} / \mathrm{kg}$ of pronethalol were injected $60 \mathrm{~min}$ earlier (Table 5). Neither DCI nor pronethalol affected the cyclic AMP content of the sham-operated brain.

Reserpine was given to deplete the stores of catecholamines, and the brain subsequently injured. No significant difference in cyclic AMP accumulation was observed in the reserpinized mice (Table 5).

After administration of diphenhydrazine, an antihistaminic drug, the cyclic AMP in injured brain increased only to $54 \%$ of that in untreated, injured animals $(\mathrm{P}<0.01)$. The drug alone had no effect on cyclic AMP concentration.

Theophylline has been observed to reduce the effect of electrical stimulation on 
the accumulation of cyclic AMP in slices of cerebral cortex ${ }^{23)}$. Following injection of theophylline, the injury-injuced elevations of cyclic AMP content were reduced to 37 per cent of the concentrations in injured brain.

None of the drug treatments substantially altered the cyclic AMP content of brain in sham-operated, injured mice $(0 . \overline{5}<\mathrm{P}<0.02)$ except after theophylline was given. In this instance, the cyclic AMP in drug-treated micc was greater than in the sham-operated animals $(\mathrm{P}<0.001)$.

The phenothiazine derivatives were uscd in the present study because it has been previously shown that they affect the formation of cyclic AMP in brain ${ }^{4)},{ }^{7)},{ }^{9},{ }^{20)},{ }^{21}$. Chlorpromazine diminishes the effect of depolarizing agents which act apparently by the release of adenosine. Both chlorpromazine and trifluoperazine depressed the cyclic AMP increase due to injury $(\mathrm{P}<0.001$, Table 5).

\section{Discussion}

The early changes following stab wound injury suggest the injured area of the brain is in an ischemic-anoxic condition. The decreases in glycogen, glucose, glucose6-P, A'TP and P-creatine and the increases in lactate are related to a shift to anaerobic glycolysis with a consequent greater demand on energy reserves. The rapid utilization of energy reserves in ischemic or anoxic brain has been described in mice ${ }^{18)}$, rats ${ }^{24}$ ) and monkcys ${ }^{25}$ ). The initial rise in cyclic AMP is also associated with ischemia ${ }^{2)}$, as is the conversion of phosphorylase $b$ to the $a$ form ${ }^{15)}$. The enormous incrcase in clyclic AMP may be responsible for the conversion of phosphorylase $b$ to $a$ in the traumatized brain, with consequent decrease in glycogen concentration. However, the glycogen synthetase at $1 \mathrm{~min}$ after injury has the highest percentage of the $\mathbf{I}$ form scen at any time, although cyclic AMP stimulates the formation of synthetase $\mathrm{D}$. Apparently, the

Table 1. Trauma-injuced alteration in levels of cerebral glycogen

Mice were quick-frozen at the times indicated after brain injury. The glycogen from the cercbral cortex near the vicinity of the lesion was measured as described in Materials and Methods. Values \pm S.E.M. for 4 animals in each group. The concentration of glycogen is expressed as mmoles of anhydro-glucosyl units $/ \mathrm{kg}$ wet weight of tissue. Statistically significant differences in values from the corresponding sham-operated control are indicated: * $P<0.01 ; * * P<0.005 ; * * * P<0.001$.

\begin{tabular}{ccc}
\hline \multirow{2}{*}{ Time after injury } & \multicolumn{2}{c}{ Glycogen (mmole/kg) } \\
\cline { 2 - 3 } & Sham-operated & Injured \\
$1 \mathrm{~min}$ & $1.88 \pm 0.10$ & $1.81 \pm 0.16$ \\
$10 \mathrm{~min}$ & $2.19 \pm 0.16$ & $1.24 \pm 0.05^{* *}$ \\
$30 \mathrm{~min}$ & $2.18 \pm 0.23$ & $1.68 \pm 0.13$ \\
$1 \mathrm{~h}$ & $2.45 \pm 0.09$ & $2.65 \pm 0.06$ \\
$1.5 \mathrm{~h}$ & $2.39 \pm 0.03$ & $3.10 \pm 0.25$ \\
$2.5 \mathrm{~h}$ & $2.59 \pm 0.20$ & $4.09 \pm 0.14^{* * *}$ \\
$6.5 \mathrm{~h}$ & $2.56 \pm 0.16$ & $4.22 \pm 0.15^{* * *}$ \\
$12 \mathrm{~h}$ & $2.55 \pm 0.36$ & $4.28 \pm 0.19^{*}$ \\
$24 \mathrm{~h}$ & $2.60 \pm 0.23$ & $4.33 \pm 0.28^{* *}$ \\
- & & -52
\end{tabular}




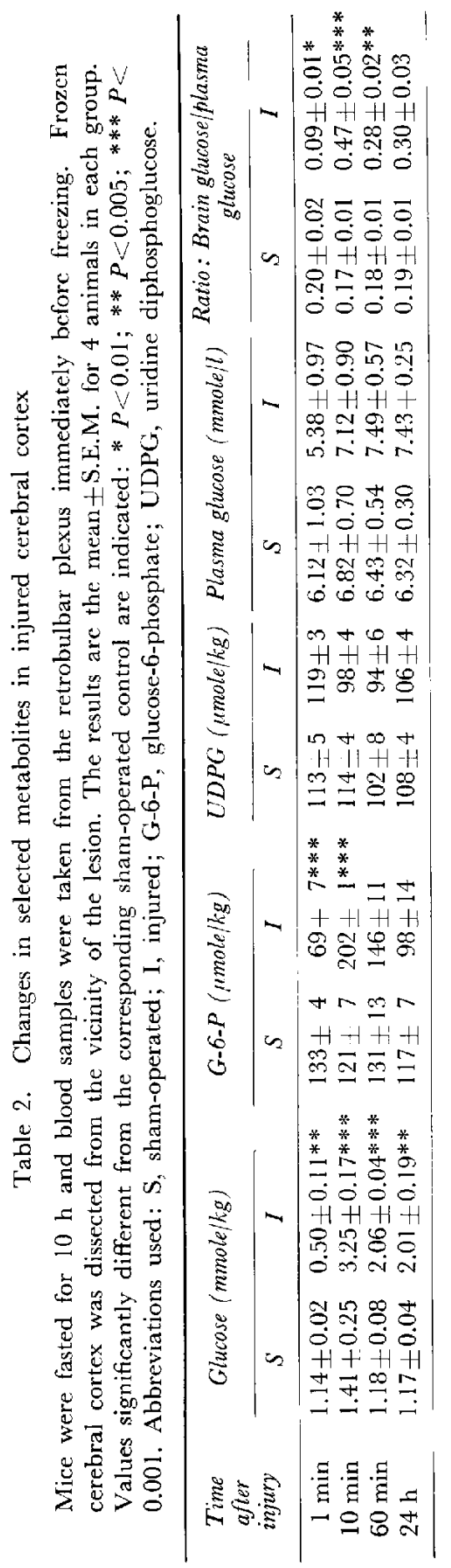

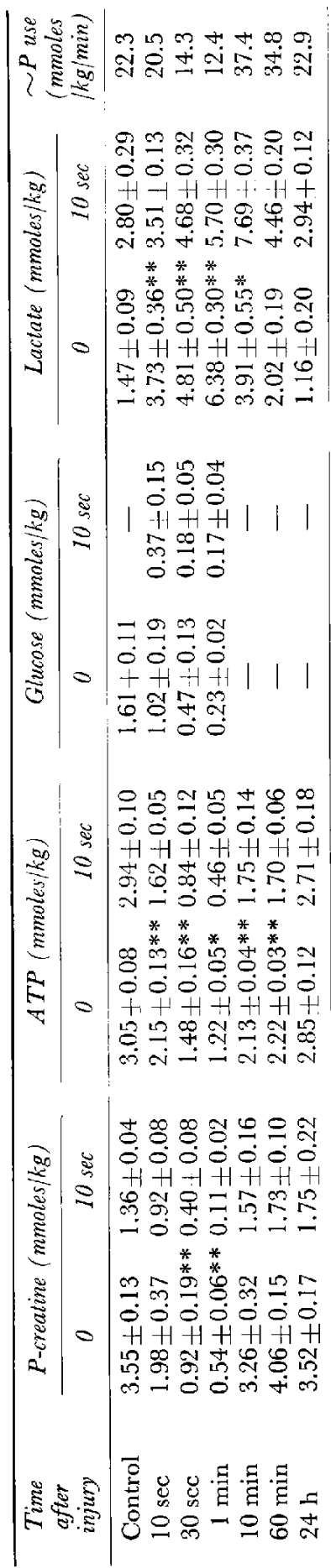


two events are dissociated in the brain, at least in the early stages of injury.

In spite of the accumulation of glycogen observed, the amount of synthetase in the active form $(I)$ is not diffcrent from controls $1 \mathrm{~h}$ after injury, and aftcr $24 \mathrm{~h}$ is in fact decreased relative to controls. Glucose is elevated in the injured brain and remains significantly higher than the control values for $24 \mathrm{~h}$. The increase in glucose may act to 'push' glycogenesis as postulated by Goldberg and O'Toole ${ }^{26)}$. Furthermorc, the decrease in the per cent of phosphorylase $a$, and the inhibition of phosphorylase by glucose ${ }^{27}$ must contribute to the process of glycogen accumulation.

The turnover of brain glycogen increased grcatly in the carly period after injury. The muximum increase in specific activity was observed $1 \mathrm{~h}$ after the stab wound (Fig. 1). However, in contrast to early changes, the specific activity of the cerebral glycogen (Fig. 2) was less in animals given ${ }^{14} \mathrm{C}$-glucose $24 \mathrm{~h}$ after injury. The lower specific activity of the glycogen can almost exactly be accounted for by the increased glycogen concentration at this time (Table 1), indicating that the rate of incorporation of label was probably not altered at that time. The rate of disappearance of the label from glycogen in the injured brain was decreased. (The half-time was 1.5 times longer than that of controls.) These observations support the suggestion of Lundgren and Miquel ${ }^{28)}$ that accumulation of cerebral glycogen in irradiated rats was the result of decreased glycogenolysis.

'The cffect of injury on the metabolic rate in brain occurred in two distinct phases. During the first minute following injury the metabolic rate was markedly depressed (Table 3). Conceivably this could be attributed to spreading depression ${ }^{29)}$ as well as to the ischemic state of the injured area. 'The P-creatine, ATP and glucose were all significantly lower than control values at the times when metabolic rate was depressed. This observation suggests there is a compensatory mechanism which regulates metabolic ratc during ischemia or hypoxia 30,31$)$. Sulsequently the metabolic rate increased to over 1.5 times that of the control. The increased metabolic rate is evident at 10 and $60 \mathrm{~min}$ after injury. It is difficult to explain such an increase.

Table 4. Effect of brain injury on glycogen synthetase and glycogen phosphorylase in mouse cerebral cortex

Mice were quick-frozen after brain injury at the times indicated. The homogenates of brain were prepared and enzyme activities measured as described in Materials and Methods. The values are the means \pm S.E.M. for 4 animals in each group. Values significantly diflerent from the corresponding sham-operated controls are indicated: $* P<$ $0.05 ; * * P<0.005$. The total cnzyme activities were $14.7 \pm 0.3 \mathrm{mmoles} / \mathrm{kg} / \mathrm{h}$ and 121 $\pm 6 \mathrm{mmoles} / \mathrm{kg} / \mathrm{h}$ for glycogen synthetase and glycogen phosphorylase, respectively.

\begin{tabular}{|c|c|c|c|c|}
\hline \multirow{3}{*}{ Time afler injury } & \multirow{2}{*}{\multicolumn{2}{|c|}{$\frac{\text { Glycogen synthetase } I}{\text { Total synthetase }}$}} & \multirow{2}{*}{\multicolumn{2}{|c|}{$\frac{\text { Phasphorylase a }}{\text { Total phosphorylase }} \%$}} \\
\hline & & & & \\
\hline & Sham-operated & Injured & Sham-operated & Injured \\
\hline $1 \mathrm{~min}$ & $32.3=3.8$ & $43.6+4.4$ & $20.2 \pm 1.7$ & $39.8 \pm 1.6 * *$ \\
\hline $10 \mathrm{~min}$ & $26.1+1.4$ & $32.6 \pm 1.2 *$ & $31.1+0.5$ & $40.4 \pm 1.9 * *$ \\
\hline $60 \mathrm{~min}$ & $31.5 \pm 0.9$ & $29.7+1.9$ & $30.7+0.7$ & $35.7 \pm 2.6$ \\
\hline $24 \mathrm{~h}$ & $25.6 \pm 1.8$ & $20.8 \pm 0.9^{*}$ & $31.3 \pm 0.6$ & $24.3 \pm 2.2$ \\
\hline
\end{tabular}


Transport of glucose into the brain has been implicated as a rate limiting step in glycolysis ${ }^{32}$ ). The increased levels of glucose at these times (Table 2) may indicate increased transport of glucose which in turn serves to accelerate metabolism. The energy requirements for maintaining ion balance may also be increased after injury.

Cyclic AMP concentrations have been shown to increase in brain following decapitation ${ }^{2)}{ }^{4)}$ and electrical stimulation ${ }^{33)}$. These increases have been attributed to the formation of adenosine ${ }^{33)}$ which is postulated to activate adenyl cyclase through interaction with a receptor on the plasma membrane. Such an interpretation agrees with the effect of depolarizing agents on brain slices ${ }^{34}$.

In this study, we showed that stab wound injury resulted in a 7-fold increase in cyclic AMP in the brain, with a concomitant doubling of phosphorylase in the active form (a) and a subsequent decrease in glycogen content. It is possible that in this case, as in decapitation, the local ischemia and anoxia are responsible for the observed increases in cyclic AMP. Since anoxia rcsults in decreases in phosphorylated adenine nucleotides ${ }^{35}$, the resulting formation of adenosine could activate the adenyl cyclase. The effect of theophylline in preventing the rise in cyclic AMP following stab wound injury lends further credibility to this interpretation, since theophylline has been demonstrated to block the adenosine-stimulated accumulation of cyclic AMP in brain slices ${ }^{23}$.

Table 5. Effect of centrally acting drugs on the cyclic AMP changes injuced by brain injury

\begin{tabular}{|c|c|c|c|c|}
\hline \multirow[t]{2}{*}{ Treatment } & \multicolumn{2}{|c|}{$\begin{array}{c}\text { Cyclic } 3^{\prime}, 5^{\prime} A M P \\
(\mu \text { mole } / \mathrm{kg})\end{array}$} & \multirow{2}{*}{$\begin{array}{l}\text { Pcrcent of Cyclic } \\
\text { AMP in Injured, } \\
\text { Untreated Mice }\end{array}$} & \multirow{2}{*}{ P Value } \\
\hline & Sham operated & Injured & & \\
\hline None & $1.70 \pm 0.07$ & $15.10 \pm 2.08$ & 100 & - \\
\hline $\begin{array}{l}\text { DCI } \\
(10 \mathrm{mg} / \mathrm{kg}, 60 \mathrm{~min})\end{array}$ & $1.46 \pm 0.06$ & $11.23 \pm 1.08$ & 74.4 & $<0.1$ \\
\hline $\begin{array}{l}\text { DCI } \\
(25 \mathrm{mg} / \mathrm{kg}, 60 \mathrm{~min})\end{array}$ & $1.53 \pm 0.08$ & $10.91 \pm 0.82$ & 72.2 & $<0.1$ \\
\hline $\begin{array}{l}\text { Pronethalol } \\
(10 \mathrm{mg} / \mathrm{kg}, 60 \mathrm{~min})\end{array}$ & $1.58 \pm 0.09$ & $8.50 \pm 1.52$ & 56.3 & $<0.05$ \\
\hline $\begin{array}{l}\text { Pronethalol } \\
(25 \mathrm{mg} / \mathrm{kg}, 60 \mathrm{~min})\end{array}$ & $1.43 \cdot \pm .0 .07$ & $12.59 \pm 1.93$ & 83.4 & $<0.5$ \\
\hline $\begin{array}{l}\text { Reserpine } \\
(10 \mathrm{mg} / \mathrm{kg}, 4 \mathrm{~h})\end{array}$ & $1.24 \pm 0.28$ & $11.69 \pm 2.36$ & 77.4 & $<0.3$ \\
\hline $\begin{array}{l}\text { Theophylline } \\
(100 \mathrm{mg} / \mathrm{kg}, 30 \mathrm{~min})\end{array}$ & $2.30 \pm 0.09$ & $5.59 \pm 0.55$ & 37.0 & $<0.001$ \\
\hline $\begin{array}{l}\text { Diphenphydramine } \\
\text { (40 mg/kg, } 30 \mathrm{~min})\end{array}$ & $1.63+0.08$ & $8.21 \pm 0.97$ & 54.4 & $<0.01$ \\
\hline $\begin{array}{l}\text { Chlorpromazine } \\
(20 \mathrm{mg} / \mathrm{kg}, 90 \mathrm{~min})\end{array}$ & $1.32+0.12$ & $6.55 \pm 0.57$ & 43.4 & $<0.001$ \\
\hline $\begin{array}{l}\text { Trifiuoperanine } \\
(20 \mathrm{mg} / \mathrm{kg}, 90 \mathrm{~min})\end{array}$ & $\Upsilon .24 \pm 0.12$ & $6.51 \pm 0.94$ & 43.1 & $<0.001$ \\
\hline
\end{tabular}

There were 4 animals in each group. After prior treatment of drugs for the times indicated, animals were injured and whole body frozen at $1 \mathrm{~min}$ after injury as described in Materials and Methods. Values for cyclic AMP indicate mean \pm SEM. DCI indicates dichloroisoproterenol. 
The peak level of cyclic AMP in the brain is reached 1 min after injury, following which the concentration falls rapidly. Several possibilities may account for this observation: 1) the adenosine may be phosphorylated or deaminated and so have no further effect on stimulating adenyl cyclase. 2) The phosphodiesterase activity in the presence of increased substrate concentration may contribute to the decrease in cyclic AMP. If the adenyl cyclase were already maximally stimulated, the activity of the phosphodiesterase may then serve to establish a new steady state.

Several diverse agents including biogenic amines, adenosine and inorganic ions have been shown to increase cyclic AMP concentrations in brain slices. Burkard has shown that injection of catecholamines into the cerebral ventricles increased the cyclic AMP in rat brain. In the present investigation, the lack of effect of antiadrenergic agents suggests that norepinephrine is not involved. Furthermore, pretreatment of the mice with reserpine did not diminish the response to stab wound injury.

Theophylline, chlorpromazine inhibited the increase in cyclic AMP observed after stab wound injury. Theophylline has been shown to depress the accumulation of cyclic AMP induced by electrical stimulation in cerebral slices, in which the relcase of adenosine is postulated7). Chlorpromazine has been shown to diminish the depolarizing effects of electrical stimulation. The effect of depolarizing agents in elevating cyclic AMP concentration in brain slices appears to be mcdiated by the release of adenosine ${ }^{23), 36)}$. The present observations are consistent with a release of adenosine provoked by stab wound injury, and the consequent ischemia and membrane depolarization.

\section{References}

1) Sutherland, E. W., and Rall, T. W.: The relation of adenosine 3', 5'-phosphate and phosphorylase to the action of catecholamines and other hormones. Pharmacol. Rev., 12: 265-298, 1960.

2) Breckenridge, B. M.: The mcasurement of cyclic adenylate in tissues. Proc. Natl. Acad. Sci., 52: 1580-1586, 1964.

3) Kakiuchi, S., and Rall, T. W.: The influcnce of chemical agents on the accumulation of adcnosine 3 ', 5'-phosphate in slices of rabbit cerebellum. Mol. Pharmacol., 4: 367-378, 1968.

4) Kakiuchi, S., and Rall, T. W.: Studies on adenosince $3^{\prime}, 5^{\prime}$-phosphate in rabbit cerebral cortex. Mol. Pharmacol., 4: 379-388, 1968.

5) Pauk, G. J., and Reddy, W. J. : Measurement of adenosine $3^{\prime}, 5^{\prime}$-monophosphate. Analyt. Biochem., 21: 298-307, 1967.

6) Weiss, B., and Costa, E: Regional and subcellular distribution of adenyl cyclase and 3', 5 '-cyclic nucleotide phosphodiesterase in brain and pineal gland. Biochem. Pharmacol,, 17: 2107-2116, 1968.

7) Kakiuchi, S., Rall, T. W., and McIlwain, H.: The effect of electrical stimulation upon the accumulation of adenosine 3 ', 5'-phosphate in isolated ccrebral tissue. J. Neurochem., 16: 485-491, 1969.

8) Goldbcrg, N. D., Lust, W. D., O'Dea, R. F., Wei, S., and O'Toole, A.G. : A role of cyclic nucleotide in brain metabolism. Eds. P. Greengard and E. Costa. Role of cyclic AMP in cell Function. Advances in Biochemical Psychopharmacology, Vol. 3, New York, Raven Press, 1970. 
9) Watanabe, H., and Passonneau, J. V.: The effect of trauma on cerebral glycogen and related metaboltes and enzymes. Brain Res., 66:147-159, 1974.

10) Hirata, M., and Hayaishi, O.: Adenyl cyclase of Brevibacterium liquefaciens. Bioch. Biophys. Acta, 149: 1-11, 1967.

11) Rall, T. W., and Sutherland E. W.: Adenyl cyclase. II. The enzymatically catalyzed formation of adenosine $3^{\prime}, 5^{\prime}$-phosphate and inorganic pyrophosphate from adenosine triphosphate. J. Biol. Chem., 237: 1228-1232, 1962.

12) Nelson, S. R., Schulz, D. W., Passonneau, J. V., and Lowry, O. H. : Control of glycogen levels in brain. J. Neurochem., 15: 1271-1279, 1968.

13) Brunner, E. R., Passonneau, J. V., and Molstad, C.: The effect of volatile anesthetics on levels of metabolites and metabolic rate in brain. J. Neurochem., 18: 2301-2316, 1971.

14) Passonneau, J. V., and Rottenberg, D. A. : An assessment of methods for measurement of glycogen synthetase including a new direct one-step assay. Analyt. Biochem., 51: 528$541,1973$.

15) Breckenridge, B. M., and Norman, J. H.: Glycogen phosphorylase in brain. J. Neurochem., 9: 383-392, 1962.

16) Watanabe, H., and Passonncau, J. V.: Factors affecting the turnover of cerebral glycogen and limit dextrin in vivo. J. Neurochem., 20: 1543-1554, 1973.

17) Passonneau, J. V., Gatfield, P. D., Schulz, D. W., and Lowry, O. H. : An enzymic method for measurement of glycogen. Analyt. Biochem., 19: 315-326, 1967.

18) Lowry, O. H., Passonneau, J. V., Hasselberger, F. X., and Schulz, D. W.: Effect of ischemia on known substrates and cofactors of the glycolytic pathway in brain. J. Biol. Chem., 239: 18-30, 1964 .

19) Lowry, O. H., Schulz, D. W., and Passonneau, J. V.: The kinetics of glycogen phosphorylase from brain and muscle. J. Biol. Chem., 242: 271-280, 1967.

20) Gilman, A. G.: A protein binding assay for adenosine $3^{\prime}, 5^{\prime}$-cyclic monophosphate. Proc. Nat. Acad. Sci. (Wash), 67: 305-312, 1970.

21) Klainer, L. M., Chi, Y. M., Friedberg, S. L., Rall, T. W., and Sutherland, E. W.: Adenyl cyclase: IV. The effects of neurohormones on the formation of adenosine 3', 5'-phosphate by preparations from brain and other tissucs. J. Biol. Chem., 237: 1239$1243,1962$.

22) Burkard, W. P.: Catecholamine induced increase of cyclic adenosine 3', 5'-monophosphate in rat brain in vivo. J. Neurochem. 19: 2615-2619, 1972.

23) Sattin, A., and Rall, T. W.: The effect of adenosine and adenine mucleotides on the cyclic adenosine 3', 5'-phosphate content of guinea pig cerebral cortex slices. Mol. Pharmacol., 6; 13-23, 1970.

24) Clendenon, N. R., Allen, N., Komatsu, T., Liss, L., Gordon, W., and Heimberger, K.: Biochemical alteration in the anoxic-ischemic lesion of rat brain. Arch. Neurol. (Chic), 25: 432-448, 1971.

25) Rivera, A., Brann, A. W., and Myers, R. E.: Brain glycogen of the recovering asphyxiated monkey ncwborn. Fxp. Neurol., 26: 309-315, 1970.

26) Goldberg, N. D., and O'Toole, A. G.: The properiies of glycogen synthetase and regulation of glycogen biosynthesis in rat brain. J. Biol. Chem., 244: 3053-3061, 1969.

27) Cori, C. F., Corl, G. T., and Green, A. A.: Crystalline muscle phosphorylase III kinetics. J. Biol. Chem., 151 : 39-55, 1943.

28) Lundren, P. R., and Miquel, J.: The incorporation of isotopic carbon ${ }^{14} \mathrm{C}$ into cerebral glycogen of normal and X-irradiated rats. J. Neurochem., 17: 1383-1386, 1970.

29) Leao, A. A. P.: Spreading depression of activity in the cerebral cortex. J. Neurophysiol., $7: 359-390,1944$. 
30) Duffy, T. E., Nelson, S. R., and Lowry, O. H.: Cerebral carbohydrate metabolism during acute hypoxia and recovery. J. Neurochem., 19:959-977, 1972.

31) Stewart, M. A., Passonneau, J. V., and Lowry, O. H.: Substrate changes in peripheral nerve during ischemia and Wallerian degeneration. J. Neurochem., 12: 719-727, 1965.

32) Marke, H. S., and Lehrer, G. M.: Carbohydrate chemistry of brain. In R.W. Albers, G. J. Siegel, R. Katzman, and B. W. Abranoff (Eds.), Basic Neurochemistry, Little Brown, Boston, Mass., 1972, pp. 169-189.

33) Sattin, A.: Increase in the content of adenosine $3^{\prime}, 5^{\prime}$-monophosphate in mouse forebrain during seizures and prevention of the increase by methylxanthines. J. Neurochem., 18: 1087-1096, 1971.

34) Shimizu, H., Cyrus, R. C., and Daly, J. W.: Stimulated formation of adenosine 3', 5'cyclic monophosphate in cerebral slices. Europ. J. Pharmacol., 17: 240-252, 1972.

35) Collins, R. C., Posner, J. V., and Plum, F.: Cerebral energy metabolism during clectroshock seizures in mice. Amer. J. Physiol., 218: 943-950, 1970.

36) Shimizu, H., Cyrus, R. C., and Daly, J. W.: Stimulated formation of adenosine 3', 5'cyclic phosphate in cerebral cortex: Synergism between electrical activity and biogenic amines. Proc. Nat. Acad. Sci. (Wash), 65 : 1033-1040, 1970. 